\title{
DAMPAK OLAHRAGA WISATA BAGI MASYARAKAT
}

\author{
Oleh: \\ I Ketut Sudiana \\ Jurusan Ilmu Keolahragaan \\ Fakultas Olahraga Dan Kesehatan \\ Universitas Pendidikan Ganesha
}

\begin{abstract}
ABSTRAK
Olahraga wisata merupakan salah satu jenis kegiatan wisata yang perkembangannya cukup pesat di Indonesia karena memiliki pegunungan, lautan, sungai dan danau yang begitu luas. Oleh karena masing-masing daerah memiliki karakteristik geografis yang berbeda maka pengembangan olahraga wisata sangat memungkinkan untuk dijadikan sebuah alternatif olahraga rekreasi bagi pencinta olahraga seperti olahraga gunung (mendaki, berkemah, jelajah hutan, bersepeda, atau trekking, dan sebagainya), olahraga air (diving, canoing, snorkeling, surfing, dan sebagainya)

Hubungan olahraga dan pariwisata tidak dapat dipisahkan karena keduanya dapat memberikan keuntungan satu sama lain. Bisa saja peristiwa olahraga diselenggarakan di daerah wisata dengan tujuan untuk memberikan hiburan tambahan bagi wisatawan, ataupun sebaliknya hanya dimanfaatkan khusus guna menarik wisatawan lokal maupun wisatawan asing (Danasaputra, 2009). Dengan demikian olahraga pun akhirnya dapat memicu bisnis baru seperti tempat hiburan rekreasi, restoran, perhotelan, pengembangan usaha kecil (aksesoris-aksesoris daerah setempat menjadi lebih berkembang), makanan dan minuman khas daerah setempat menjadi lebih dikenal, dan pada akhirnya dapat menciptakan lapangan kerja.

Sebagai produk dari industri olahraga, olahraga pariwisata memerlukan pengelolaan lebih lanjut agar mampu menarik minat wisatawan asing maupun lokal sebagai konsumennya.

Pengembangan olahraga pariwisata berpotensi besar sebagai daya tarik dan sarana promosi daerah setempat. Masyarakat yang datang untuk menyaksikan suatu event atau kejuaraan dapat sekaligus berwisata sementara masyarakat yang menonton kejuraan tersebut melalui tontonan televisi akan menjadi tertarik untuk mengunjungi daerah tersebut. Demikian pula akan berdampak positif bagi daerah dan masyarakat serta usaha kecil dan menengah di daerah penyelenggaraan.Penyelenggaraan olahraga pariwisata di suatu tempat secara langsung dapat pula memberikan keuntungan bagi masyarakat sekitar karena dapat membuka kesempatan berusaha seperti penyediaan makanan, minuman, usaha transportasi baik tradisional maupun konvensional.
\end{abstract}

\section{Kata Kunci: Olahraga wisata, Destinasi}




\title{
IMPACT SPORTS TOURISM FOR THE PEOPLE
}

\author{
By: \\ I Ketut Sudiana \\ Department of Sport Science \\ Faculty of Sport and Health \\ Ganesha University of Education
}

\begin{abstract}
Sports tourism is one of the types of tourism development activities rapidly in Indonesia because it has mountains, oceans, rivers and lakes are so broad. Therefore, each region has a different geographical characteristics of the development of sport tourism it is possible to be used as an alternative recreational sports for sports enthusiasts such as mountain sports (hiking, camping, jungle trekking, cycling, or trekking, etc.), water sports (diving, canoing, snorkeling, surfing, and so on)

Sport and tourism relations can not be separated because they can provide benefits to one another. Sporting events can be held in a tourist area with the aim to provide additional entertainment for tourists, or otherwise only be used specifically to attract tourists both local and foreign tourists (Danasaputra, 2009). Thus sport can eventually lead to new business as a leisure entertainment, restaurant, hospitality, small business development (accessories local area becomes more developed), food and drink typical of the local area becomes better known, and could ultimately create jobs.

As a product of the sports industry, sports tourism require further management in order to attract foreign and local tourists as consumers.

Development of sports tourism has great potential as an attraction and promotion of local areas. People who come to watch an event or championship can once traveled while the people who watch television kejuraan through the spectacle would be interested in visiting the area. Similarly, will positively impact the area and the community as well as small and medium enterprises in the region administration. Operation of sports tourism in a place directly can also provide benefits to the surrounding community because it can open up business opportunities such as the provision of food, beverages, transportation businesses both traditional and conventional.
\end{abstract}

Keywords: Sportstourism, Destination 


\section{PENDAHULUAN}

Kegiatan keolahragaan pada dasarnya tidak dapat terlepas dari kegiatankegiatan lainnya serta kehidupan masyarakat sehari-hari.Kegiatan keolahragaan sekarang ini sudah menjadi kebutuhan yang harus terpenuhi oleh manusia karena mampu memberikan tubuh menjadi lebih bugar daripada sebelumnya.Olahraga akan memberikan dampak positif kepada pelaku olahraga karena aktivitas gerak yang diperoleh selama melakukan bermacam kegiatan olahraga akan memberikan kebugaran jasmaniah dan kepuasan rohaniah bagi tubuh. Kebugaran jasmaniah yang dimaksud adalah terjadinya perubahan kondisi fisik yang lebih baik terutama pada jantung, paru-paru, dan pembuluh darah, sedangkan kepuasan rohaniah lebih menekankan kepada kepuasan bathiniah selama kegiatan olahraga itu dapat memberikan kesenangan untuk dirinya sendiri.

Kegiatan manusia modern sekarang ini telah banyak mengalami perubahan kemajuan yaitu tidak cukup pada olahraga yang bertujuan untuk kebugaran jasmani semata akan tetapi olahraga yang bersifat rekreasi pun sangat pesat perkembangannya. Hampir di seluruh belahan dunia termasuk di Indonesia, olahraga pariwisata kini semakin maju sehingga banyak bidang olahraga yang kini dijadikan destinasi bagi wisatawan, terutama olahraga yang memanfaatkan fasilitas yang bersifat alamiah seperti pegunungan, danau, sungai, dan lautan.

Aktivitas olahraga yang dilakukan secara teratur dan terprogram bagi manusia bisa menjadikan manusia seutuhnya, merasakan dalam kehidupan menjadi lebih tenang, nyaman, dan damai. Dorongan itulah menyebabkan budaya olahraga dewasa ini menjadi bagian dari kehidupan manusia yang sadar akan pentingnya kebugaran jasmani dan kepuasan rohani menjadi lebih berkembang dikehidupan masyarakat.

Kesenangan untuk berolahraga yang teratur dan sistematis serta berkesinambungan maka pelakunya senantiasa akan memperoleh kebugaran jasmani dan kesehatan rohani, sedangkan disisi lain dampak olahraga wisata sebagai salah satu sektor pembangunan dibidang ekonomi jika pengelolaannya 
dilakukan dengan baik dan sesuai dengan program pemerintah, seyogyanya dapat memberikan kontribusi besar bagi kemajuan daerah dan kesejahteraan hidup masyarakatnya (Sudiana, 2013).

\section{PEMBAHASAN}

\section{A. Konsep Olahraga Pariwisata}

Sesungguhnya olahraga pariwisata sampai saat ini belum ada yang menyepakati satu definisi tentang apa itu "Olahraga Pariwisata". Berbeda halnya dengan definisi "Olahraga" atau "Pariwisata" yang dapat diterima dengan baik di dunia. Misalnya dalam UU RI No 3 tahun 2005, dijelaskan bahwa olahraga adalah "Segala kegiatan yang sistematis untuk mendorong, membina serta mengembangkan potensi jasmani, rohani, dan sosial”.

Menurut International Council of Sport and Education yang dikutip oleh Lutan, dkk (2000) bahwa "Olahraga adalah kegiatan fisik yang mengandung sifat permainan dan berisi perjuangan dengan diri sendiri atau perjuangan dengan orang lain serta konfrontasi dengan unsur alam.”

Berdasarkan pada kedua definisi di atas, dapat disimpulkan bahwa olahraga adalah aktivitas jasmani yang mengandung sifat permainan baik melalui perjuangan sendiri maupun dengan orang lain yang dilakukan oleh seseorang atau sekelompok orang secara terprogram, sistematis, dan berkesinambungan dengan tujuan untuk mendapatkan kebugaran jasmani, rohani, dan sosial.

Komite Disiplin Ilmu (2000) menjelaskan tentang identifikasi ciri umum olahraga sebagai berikut.

1. Olahraga merupakan subsistem bermain: pelaksanaannya secara sukarela tanpa paksaan.

2. Olahraga berorientasi pada dimensi fisikal: kegiatan itu merupakan peragaan keterampilan fisik.

3. Olahraga merupakan kegiatan real, bukan ilusi atau imajinasi.

4. Olahraga, terutama kompetitif yang menekankan aspek performa dan prestasi sehingga di dalamnya terlibat unsur perjuangan, kesungguhan, dan faktor 
surprise, sebagai lawan dari faktor untung-untungan sehingga performa itu dicapai melalui usaha pribadi.

5. Olahraga berlangsung dalam suasana hubungan sosial dan bersifat kemanusiaan, bukan membangkitkan naluri rendah, dan bahkan justru membangkitkan solidaritas.

6. Olahraga harus bermuara pada upaya untuk meningkatkan dan memelihara kesehatan total atau wellness (KDI, 2000).

Demikian halnya dengan definisi "Pariwisata" yang sudah diterima di dunia, antara lain: Khodyat (1983) dan Sunaryo (2004) menyebutkan bahwa Pariwisata adalah perjalanan dari suatu tempat ke tempat lain, bersifat sementara, dilakukan oleh perorangan atau kelompok, sebagai salah satu usaha untuk mencari keseimbangan atau keserasian dan kebahagiaan dengan lingkungan hidup dalam dimensi sosial, budaya, alam, dan ilmu. Demikian pula oleh Pitana dan Gayatri (2005) mengatakan pariwisata adalah suatu kegiatan yang secara langsung menyentuh dan melibatkan masyarakat, sehingga membawa berbagai dampak terhadap masyarakat setempat.

Berdasarkan definisi di atas, dapat disimpulkan bahwa pariwisata adalah perjalanan yang dilakukan oleh perorangan atau kelompok yang bersifat sementara, dari suatu tempat ke tempat lain sebagai salah satu upaya untuk mendapatkan kebahagiaan dan keseimbangan dengan lingkungan alam dan ikut melibatkan masyarakat dalam berbagai dimensi sosial dan budaya.

Secara lengkap di dalam Undang-Undang Republik Indonesia No.10 tahun 2009 tentang Kepariwisataan dalam pasal 1 menyatakan:

a. Wisata adalah kegiatan perjalanan yang dilakukan oleh seseorang atau sekelompok orang dengan mengunjungi tempat tertentu untuk tujuan rekreasi, pengembangan pribadi, atau mempelajari keunikan daya tarik wisata yang dukunjungi dalam waktu sementara.

b. wisatawan adalah orang yang melakukan wisata. 
c. pariwisata adalah berbagai macam kegiatan wisata dan didukung berbagai fasilitas dan layanan yang disediakan oleh masyarakat, pengusaha, Pemerintah, dan Pemerintah Daerah.

d.kepariwisataan adalah keseluruhan kegiatan yang terkait dengan pariwisata dan bersifat multidimensi serta multidisiplin yang muncul sebagai wujud kebutuhan setiap orang dan Negara serta interaksi antara wisatawan dan masyarakat setempat, sesama wisatawan, pemerintah, Pemerintah Daerah, dan pengusaha.

e. daya tarik wisata adalah segala sesuatu yang memiliki keunikan, keindahan dan nilai yang berupa keanekaragaman kekayaan alam, budaya, dan hasil buatan manusia yang menjadi sasaran dan tujuan kunjungan wisata.

f. daerah tujuan wisata yang selanjutnya disebut destinasi pariwisata adalah kawasan geografis yang berada dalam satu atau lebih wilayah administrative yang di dalamnya terdapat daya tarik wisata, fasilitas umum, fasilitas pariwisata, aksesibilitas, serta masyarakat yang saling terkait dan melengkapi terwujudnya kepariwisataan.

g. usahapariwisata adalah usaha yang menyediakan barang dan/atau jasa bagi pemenuhan kebutuhan wisatawan dan penyelenggaraan pariwisata.

h.pengusaha pariwisata adalah orang atau sekelompok orang yang melakukan kegiatan usaha pariwisata.

i. industripariwisata adalah kumpulan usaha pariwisata yang saling terkait dalam rangka menghasilkan barang dan/atau jasa bagi pemenuhan kebutuhan wisata dalam penyelenggaraan pariwisata.

j. kawasan strategi pariwisata adalah kawasan yang memiliki fungsi utama pariwisata atau memiliki potensi untuk pengembangan pariwisata yang mempunyai pengaruh penting dalam satu atau lebih aspek, seperti pertumbuhan ekonomi, sosial dan budaya, pemberdayaan sumber daya alam, daya dukung lingkungan hidup, serta pertahanan dan keamanan.

k. kompetensi adalah seperangkat pengetahuan, keterampilan, dan perilaku yang harus dimiliki, dihayati, dan dikuasai oleh pekerja pariwisata untuk mengembangkan profesionalitas kerja. 
1. sertifikasi adalah proses pemberian sertifikat kepada usaha dan pekerja pariwisata untuk mendukung peningkatan mutu produk pariwisata, pelayanan, dan pengelolaan kepariwisataan.

m. pemerintahpusat, selanjutnya disebut pemerintah, adalah Presiden Republik Indonesia yang memegang kekuasaan pemerintahan Negara Republik Indonesia sebagai mana dimaksud dalam Undang-Undang Dasar Negara Republik Indonesia Tahun 1945.

n. pemerintahdaerah adalah gubernur, bupati atau walikota, dan perangkat daerah sebagai unsur penyelenggara pemerintahan daerah.

o.menteri adalah menteri yang tugas dan tanggungjawabnya dibidang kepariwisataan.

Undang-undang RI No 10 Tahun 2009 tentang kepariwisataan mengamanatkan agar sumber daya dan modal kepariwisataan dimanfaatkan secara optimal melalui penyelenggaraan kepariwisataan yang ditujukan untuk meningkatkan pendapatan nasional, memperluas, dan memeratakan kesempatan berusaha dan lapangan kerja, mendorong pembangunan daerah, memperkenalkan dan mendayagunakan daya tarik wisata dan destinasi di Indonesia serta memupuk rasa cinta tanah air dan mempererat persahabatan antar bangsa (Depbudpar, 2009).

Sampai hari ini "olahraga pariwisata" memiliki beberapa definisi mulai dari yang paling sempit, yaitu perjalanan yang semata-mata dilakukan untuk berpartisipasi dalam kegiatan olahraga kompetitif; hingga pada definisi yang lebih luas, yaitu olahraga pariwisata adalah kegiatan wisata yang dilakukan dengan melakukan aktivitas olahraga yang menyenangkan, tanpa ada unsur paksaan dan pada umumnya dilakukan di daerah objek wisata (Danasaputra, 2009).

Mutohir, 2012 mengatakan bahwa di Indonesia untuk tujuan pengembangan olahraga pariwisata (sport Tourism), dapat diartikan yaitu.

1. bepergian dengan alasan non-komersial

2. kegiatan liburan dan waktu luang 
3. semua kegiatan aktif dan pasif dalam olahraga atau partisipasi secara informal dan secara terorganisasi dengan alasan bukan komersial/bisnis dan harus meninggalkan rumah atau lokasi tempat kerja.

Sport Tourist, yaitu: individu/kelompok atau pengunjung yang tinggal minimal 24 jam dengan tujuan utama partisipasi dalam olahraga dan kunjungan daerah sebagai tujuan kedua.

Tourism Sport yaitu orang yang bepergian atau tinggal di tempat di luar lingkungan kebiasaannya dan berpartisipasi dalam kegiatan olahraga (kompetitif atau rekreasi) (Mutohir, 2012).

\section{B. Perkembangan Olahraga Pariwisata}

Kegiatan manusia modern sekarang ini telah banyak mengalami perubahan kemajuan yaitu tidak cukup pada olahraga yang bertujuan untuk kebugaran jasmani semata akan tetapi olahraga yang bersifat rekreasi pun sangat pesat perkembangannya. Hampir di seluruh belahan dunia termasuk di Indonesia, olahraga pariwisata kini semakin maju sehingga banyak bidang olahraga yang kini dijadikan objek maupun daya tarik bagi wisatawan, terutama olahraga yang memanfaatkan fasilitas yang bersifat alamiah seperti pegunungan, danau, sungai, dan lautan.

Olahraga wisata merupakan salah satu jenis kegiatan wisata yang perkembangannya cukup pesat di Indonesia karena memiliki pegunungan, lautan, sungai dan danau yang begitu luas. Oleh karena masing-masing daerah memiliki karakteristik geografis yang berbeda maka pengembangan olahraga wisata sangat memungkinkan untuk dijadikan sebuah alternatif olahraga rekreasi bagi pencinta olahraga seperti olahraga gunung (mendaki, berkemah, jelajah hutan, bersepeda, atau trekking, dan sebagainya), olahraga air (diving, canoing, snorkeling, surfing, dan sebagainya) (Danasaputra 2009).

Menurut Chong Kim (2012), Sport Tourism can be defined as people visit specific places to enjoy sport event, sport facility, and sport players.

Dari paparan tersebut sangat jelas bahwa olahraga pariwisata dapat didefinisikan sebagai olahraga mengunjungi tempat-tempat tertentu, untuk 
menikmati acara keluarga, fasilitas olahraga, dan permainan olahraga, sehingga dapat dimaknai bahwa kegiatan olahraga pariwisata dapat dilakukan bersamaan dengan keluarga sambil menikmati fasilitas olahraga yang tersedia dengan melakukan berbagai permainan olahraga sehingga secara langsung dapat diperoleh kebugaran jasmani dan kepuasan batiniah.

Menurut Fandeli (2001), bahwa wisata dengan berolahraga di alam terbuka merupakan sensasi tersendiri apabila tantangan tersebut dapat berakhir dengan kesuksesan. Berolahraga di alam terbuka dewasa ini merupakan salah satu komoditi pariwisata yang mampu membuat wisatawan menjadi betah di daerah tujuan wisata. Hal ini disebabkan kondisi alam yang masih asri dan sejuk, disamping ditunjang dengan sarana prasarana yang memadai.

\section{Dampak Hubungan Olahraga dan Pariwisata}

Hubungan olahraga dan pariwisata tidak dapat dipisahkan karena keduanya dapat memberikan keuntungan satu sama lain. Bisa saja peristiwa olahraga diselenggarakan di daerah wisata dengan tujuan untuk memberikan hiburan tambahan bagi wisatawan, ataupun sebaliknya hanya dimanfaatkan khusus guna menarik wisatawan lokal maupun wisatawan asing (Danasaputra, 2009). Dengan demikian olahraga pun akhirnya dapat memicu bisnis baru seperti tempat hiburan rekreasi, restoran, perhotelan, pengembangan usaha kecil (aksesoris-aksesoris daerah setempat menjadi lebih berkembang), makanan dan minuman khas daerah setempat menjadi lebih dikenal, dan pada akhirnya dapat menciptakan lapangan kerja.

Sebagai produk dari industri olahraga, olahraga pariwisata memerlukan pengelolaan lebih lanjut agar mampu menarik minat wisatawan asing maupun lokal sebagai konsumennya. Pengelolaan tersebut harus secara bergayut dan direncanakan dengan baik, akan mampu memberikan dampak yang positif bagi pembangunan pariwisata dan pada akhirnya akan mampu mendorong peningkatan penerimaan devisa daerah.

Danasaputra (2009) mengatakan secara langsung perkembangan olahraga pariwisata dapat memberikan keuntungan yang besar pada pemerintah dalam hal: 
1. meningkatkan ekonomi disekitar pariwisata olahraga berlangsung;

2. meningkatkan area wisata yang potensial;

3. berbagi informasi dengan orang-orang untuk menstimulsi partisipasi aktif mereka;

4. meningkatkan kerjasama antar pemerintah pusat dengan daerah dalam mengontrol atraksi wisata dan objek wisata;

5. mengembangkan dan menemukan objek wisata baru untuk meningkatkan objek wisata yang sudah ada;

6. meningkatkan kesempatan kerja;

7. meningkatkan produk-produk dan pemasaran lokal dalam segala aspek pariwisata;

8. memperkenalkan berbagai jenis budaya daerah, dan pencinta olahraga yang dipertandingkan atau dijadikan atraksi olahraga.

Pengembangan olahraga pariwisata berpotensi besar sebagai daya tarik dan sarana promosi daerah setempat. Masyarakat yang datang untuk menyaksikan suatu event atau kejuaraan dapat sekaligus berwisata sementara masyarakat yang menonton kejuraan tersebut melalui tontonan televisi akan menjadi tertarik untuk mengunjungi daerah tersebut. Demikian pula akan berdampak positif bagi daerah dan masyarakat serta usaha kecil dan menengah di daerah penyelenggaraan.

Penyelenggaraan olahraga pariwisata di suatu tempat secara langsung dapat pula memberikan keuntungan bagi masyarakat sekitar karena dapat membuka kesempatan berusaha seperti penyediaan makanan, minuman, usaha transportasi baik tradisional maupun konvensional.

Bali sebagai destinasi wisata, diharapkan dapat memberikan manfaat bagi pemerintah dan masyarakat karena kegiatan olahraga wisata (sport tourism) merupakan salah satu aktivitas yang disenangi oleh lapisan masyarakat lokal atau wisatawan asing karena dilakukannya pada waktu senggang dengan tujuan mendapatkan kepuasan jasmani dan rohani

\section{PENUTUP}


1. Olahraga akan memberikan dampak positif kepada pelaku olahraga karena aktivitas gerak yang diperoleh selama melakukan bermacam kegiatan olahraga akan memberikan kebugaran jasmaniah dan kepuasan rohaniah bagi tubuh. Kebugaran jasmaniah yang dimaksud adalah terjadinya perubahan kondisi fisik yang lebih baik terutama pada jantung, paru-paru, dan pembuluh darah, sedangkan kepuasan rohaniah lebih menekankan kepada kepuasan bathiniah selama kegiatan olahraga itu dapat memberikan kesenangan untuk dirinya sendiri.

2. Olahraga pariwisata dapat didefinisikan sebagai olahraga mengunjungi tempat-tempat tertentu, untuk menikmati acara keluarga, fasilitas olahraga, dan permainan olahraga, sehingga dapat dimaknai bahwa kegiatan olahraga pariwisata dapat dilakukan bersamaan dengan keluarga sambil menikmati fasilitas olahraga yang tersedia dengan melakukan berbagai permainan olahraga sehingga secara langsung dapat diperoleh kebugaran jasmani dan kepuasan batiniah.

\section{DAFTAR PUSTAKA}

ChafidFandeli, (2001). Dasar-Dasar Manajemen Kepariwisataan Alam, Yogyakarta: Penerbit Liberti.

Danasaputra, Iim Rogayah 2009. http://indanasaputra.blogspot. Com. 2009/11/pariwisataolahraga.html. diakses pada tgl 02 November 2009, diunduh pada tanggal 02 Nvember 2011

Direktorat Jendral Pendidikan Tinggi-Diknas, 2000. Komisi Disiplin Ilmu Keolahragaan,Ilmu Keolahragaan dan Rencana Pengembangannya, Jakarta: Diknas.

Kemenegpora R.I. 2005. Undang-Undang Republik Indonesia, No 3, 2005. Tentang Sistem Keolahragaan Nasional, Jakarta: Kementrian Negara Pemuda dan Olahraga Republik Indonesia.

Khodiyat, 1983. Kegiatan Pariwisata di Indonesia. Yogyakarta: PSLHUGM.KSDA,2000. Informasi Potensi Kawasan Konservasi Provinsi Bali, Denpasar: diterbitkan oleh Unit KSDA Bali.

Kim, Chong. 2012. "The Strategies For Generating Economic Values of Sport Tourism: Case of Korea", Paper presented at International 
Conference of Sport Industry; Tapping Economic Value of Sport Tourism, Denpasar, Bali.

Lutan, dkk. 2000. Manusia dan Olahraga. Bandung:FOK IKIP Bandung.

Maheswari, Istri, 2010. Strategi Pengembangan Ekowisata di Kawasan Danau Buyan, Desa Pancasari, Kabupaten Buleleng. Tesis Magister Kajian Pariwisata, Universitas Udayana, Denpasar Bali.

Mutohir, Toho Cholik, 2012. "Sport Tourism Industry:A Case of Indonesia". Paper presented at International Conference of Sport Industry; Tapping Economic Value of Sport Tourism, Denpasar, Bali.

Pitana, I Gde dan Gayatri, G Putu, 2005. Sosiologi Pariwisata, Yogyakarta: Penerbit ANDI.

Sudiana, I Ketut, 2013. Pengembangan Model Pemberdayaan Kawasan Danau Buyan Sebagai Ikon Sport Tourism Buleleng Bali. Disertasi, Universitas Negeri Surabaya.

Undang-Undang Republik Indonesia No 10, 2009. Tentang Kepariwisataan, Presiden Republik Indonesia, Jakarta: Departemen Kebudayaan dan Pariwisata.

Undang-Undang Republik Indonesia tentang Kepariwisataan, 2009. Jakarta: Departemen Kebudayaan dan Pariwisata Republik Indonesia. 